\title{
各種補修モルタルを用いたコンクリート躯体の延命化予測に関する実験的研究 PREDICTION OF PROLONGED SERVICE LIFE OF CONCRETE AFTER REPAIR WITH REPAIR MATERIALS
}

\author{
井上和 政*1, 三井健 郎*2，柳 橋邦 生*1，池 尾 陽 作*3，三 好徹 志*4 \\ Kazumasa INOUE, Kenro MITSUI, Kunio YANAGIBASHI, \\ Yosaku IKEO and Tetsushi MIYOSHI
}

\begin{abstract}
In a case of prolonged service life of old concrete structures by repair works, prediction technique of service life after repair is necessary to design durability of repaired structures.

In this paper, carbonation speed about concrete repaired by several types of repair materials after carbonation were examined. Air permeability, pore size distribution, and carbonation speed of repair materials were also examined. And effects of these repair materials on carbonation speed of concrete were confirmed. From these results, some expression to predict prolonged service life that the carbonation speed of concrete repaired correlates closely with the air permeability and carbonation speed of repairing materials was proposed. And the flow of selecting repair materials for prolonged service life of old concrete structures, was proposed.
\end{abstract}

\author{
Keywords : Concrete, Carbonation, Repair Materials, Air Permeability \\ Predict Prolonged Service Life, \\ コンクリート, 中性化, 補修材, 透父係数, 延命化
}

\section{1.はじめに（本研究の背景）}

既你躯体のリニューアルによる延命化により、コンクリート躯体 （スケルトン）の長寿命化を尖現していくためには、補修「法・材料

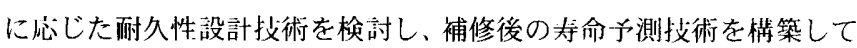
いく必姕がある。㮔々の補修に法・材料の内、将来のリサイクル性が 高く、しかも補修に:法が最も簡便なものとして、モルタル系の補修材 料による断自補修，断向被覆「法が考えられる。新規コンクリートに おける仕 I:げ材や補修材料の中性化抑制効果は、例えば中性化速度比 等として示されている1) 施。しかしがら、これらの補修後の中性化 抑制効果に関する研究は少なく、補修時期が中性化抑制効果に及ぼす 影響や、透父係数( (i) 交などの材料物性值から事前に補修後の中性化抑 制糼果を予測することを日的とした研究はほとんど見られない。

本研究では、まずモルタル系の条㮔断洎補修，断䚾被覆材料の基礎 物性試験を行い、间一試験条件で統一的な評価を行った。次に、名種 断们補修・被覆材料を开いた場合の中性化抑制機構を把握し、寿命予 测技術を確治していくために、所定量まで中性化させたコンクリート 供試体に齐断(自補修・被覆材料を被覆し、補修・被覆後の中性化抑制 効果を室内試験によって把垤した。そして、促進期開 1 年までの空内 材料試験結果に基づいた補修後の俦命予测式を構築し、検封した ${ }^{81}$ ９。 本報では、これらの垁験的な研究をまとめた結果について報告する。

\section{2. 各種室内試験の概要}

\section{1 使用材料とコンクリートの調合}

使用材料を表一 1 に、コンクリートの調合を表ー 2 に示す。コンク リートは近年補修時期を迎える建物の強度水準と現行の平均水淮と し、日噤スランプが $18 \pm 2.5 \mathrm{~cm}$, 日槽空メ量が $4.5 \pm 1.0 \%$ となるよう に調合した。練混ぜは、谷量 100ノの強制練りパン形ミキサを州い、練

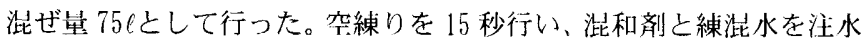
して 30 秒、ケレン後 75 秒閏練混ぜた。条補修材料は、ホバート形ミ キサを州いて食材料投人後、低速で 30 秒，槀速で 60 秒閉練混ぜた。

表 -1 使用材料

\begin{tabular}{|c|c|}
\hline セメント & 普通ポルトランドセメント (密度 $\left.3.16 \mathrm{~g} / \mathrm{cm}^{3}\right)$ \\
\hline 細骨材 & 君津産山砂 (密度 $2.61 \mathrm{~g} / \mathrm{cm}^{3}$ ，吸水率 $1.85 \%$ ) \\
\hline 粗骨材 & 八王子産山砂 (密度2. $67 \mathrm{~g} / \mathrm{cm}^{3}$, 実積率59. 3\%) \\
\hline 混和剤 & A E減水剂標準型 I 種 \\
\hline 補修材料 & 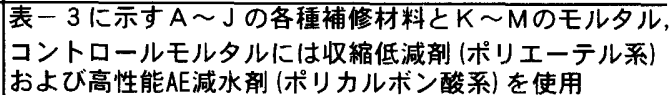 \\
\hline
\end{tabular}

表ー 2 コンクリートの調合表

\begin{tabular}{|c|c|c|c|c|c|c|c|c|c|}
\hline \multirow{2}{*}{$\begin{array}{l}\text { セxント } \\
\text { の種類 }\end{array}$} & \multirow{2}{*}{$\begin{array}{c}\text { スランブ } \\
(\mathrm{cm}) \\
\end{array}$} & \multirow{2}{*}{$\begin{array}{c}W / C \\
(\%)\end{array}$} & \multirow{2}{*}{$\begin{array}{c}\text { 空気量 } \\
(\%)\end{array}$} & \multirow{2}{*}{$\begin{array}{c}\text { 細骨材率 } \\
(\%)\end{array}$} & \multicolumn{4}{|c|}{ 単位量 $\left(\mathrm{kg} / \mathrm{m}^{3}\right)$} & \multirow{2}{*}{$\begin{array}{l}\text { 混和剂 } \\
(\mathrm{C} * 0.2 \%) \\
\end{array}$} \\
\hline & & & & & 水 & セxント & 紐骨材 & 粗骨材 & \\
\hline 普通 & 18 & 70 & 4.5 & 49.3 & 170 & 243 & 910 & 956 & 0.486 \\
\hline 普通 & 18 & 50 & 4.5 & 46.2 & 170 & 340 & 815 & 972 & 0.680 \\
\hline
\end{tabular}

本論文は，参考文献8), 9)で発表したものに，新たな試験結果を加えて考察したものである。

*1 侏竹中工務店技術研究所 主任研究員 - 博士(工学) Chief Researcher of Research and Development Institute, Takenaka Corporation,

*2 侏竹中工務店技術研究所 主席研究負・工修

*3 侏竹中工務客技術研究所 主任研究員・王修

*4 (侏)竹中工務店技術研究所 研究員 $\cdot$ 工修

Dr. Eng.

Senior Researcher of Research and Development Institute, Takenaka Corporation,
M. Eng. M. Eng.

Researcher of Research and Development Institute, Takenaka Corporation, M. Eng. 
表 -3 実験の因子と水準

\begin{tabular}{|c|c|c|c|c|c|c|}
\hline \multirow[t]{2}{*}{ 番号 } & \multirow[t]{2}{*}{ 記㕺 } & \multirow[t]{2}{*}{ 材料名 } & \multirow{2}{*}{$\begin{array}{c}\text { 淕厚さ } \\
(\mathrm{mm})\end{array}$} & \multicolumn{3}{|c|}{ 前中性化深ざ $(\mathrm{mm})$} \\
\hline & & & & 实験 I & 実騃 II & 英験吕 \\
\hline & A & A材料 (防錆・防食アクリル系ポリマーセメントモルタル & \multirow{12}{*}{10} & & \multirow{12}{*}{20} & 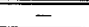 \\
\hline 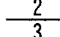 & $\frac{B}{C}$ & 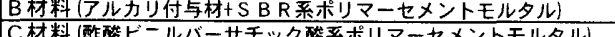 & & $0,10,30$ & & \multirow{3}{*}{14} \\
\hline & $\mathrm{D}$ & 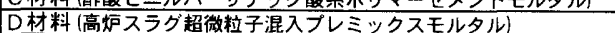 & & \multirow{3}{*}{ - } & & \\
\hline & $E$ & E材料 (エチレン酢酸ビニル采术リマーモルタル) & & & & \\
\hline & $\mathrm{F}$ & F材料（カチオン性S BRラテックスポリマーモルタル & & & & \multirow[b]{2}{*}{14} \\
\hline & G & G材料(ポリマーセメントモルタル(S BRラテテックス湜和液)) & & 0.10 .30 & & \\
\hline & $\mathrm{H}$ & H材料(一材型S B R系术リマーセメントモルタル & & \multirow{6}{*}{ - } & & \multirow{3}{*}{-} \\
\hline & 1 & 1材料(ポリマーセメントモルタル(アクリルゴム系エマルションク) & & & & \\
\hline & $\mathrm{J}$ & 了材料 (カチオン性アクリルポリマーモルタル) & & & & \\
\hline & $\mathrm{K}$ & コントロール用モルタルW $/ C=30 \%$ & & & & 14 \\
\hline & & コントロール用モルタルW/C = $40 \%$ & & & & \\
\hline & $\mathrm{M}$ & ロントロール用モルタルW/C =50\% & & & & 14 \\
\hline & Q & コントロール用被覆なし & - & & & - \\
\hline
\end{tabular}
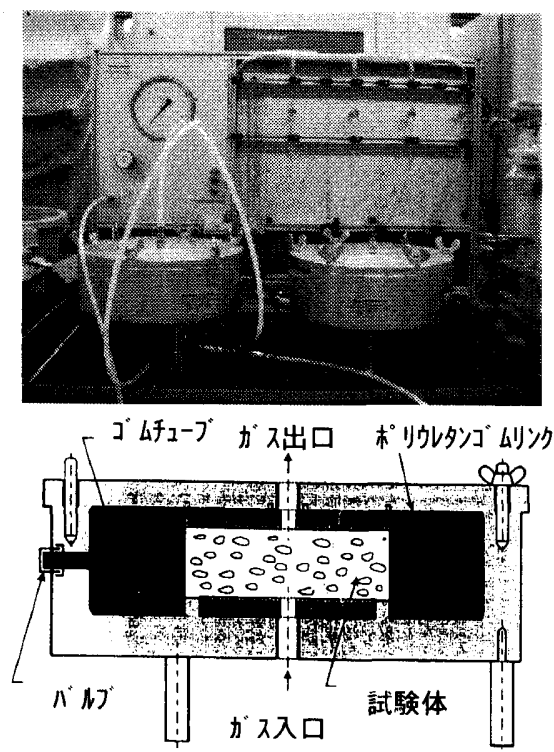

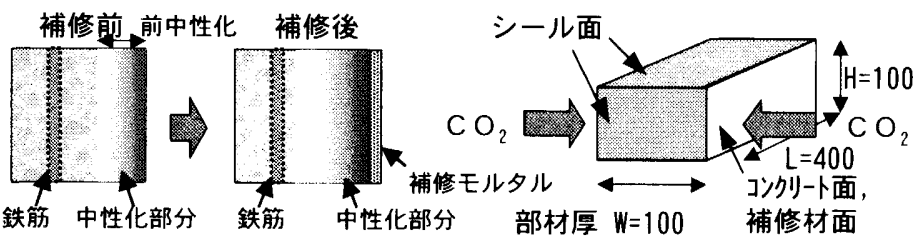

図-1 中性化試験および試験体の概要

\section{2 実験の因子と水準}

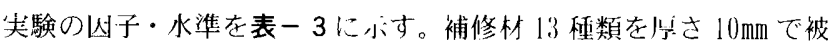

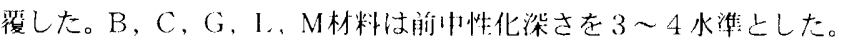

2 . 3 試験体の概要と実験方法

試験休概岀を図ー 1 にハす。練にり陹後にフレッシュ試娩を行い，

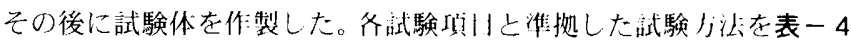

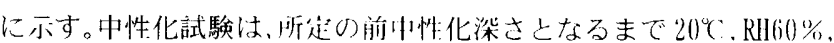

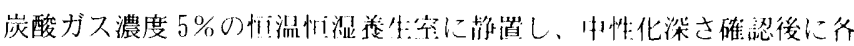

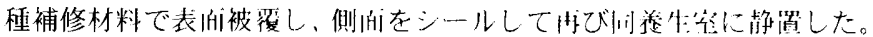

\section{表-4 試験項目および試験方法}

\begin{tabular}{|c|c|}
\hline 試験項目 & 試験方法，準拠·参考基準ほか \\
\hline スランプ & JIS A 1101に従って測定 \\
\hline 空気量 & JIS A 11281に従って測定 \\
\hline 厓縮強度 & JIS A 11081に従つて測定，供試体: $\phi 10 \times \mathrm{h} 20 \mathrm{~cm} ，(\mathrm{~N}=3)$ \\
\hline ヤング係数 & JIS A 11491に従つて測定，供試体: $\phi 10 \times \mathrm{h} 20 \mathrm{~cm} （ \mathrm{~N}=3)$ \\
\hline 中性化深さ & JIS A 1153l従つて測定，供試体: $10 \times 10 \times 40 \mathrm{~cm} ，(\mathrm{~N}=2)$ \\
\hline モルタルフロー & JIS R 5201に従って測定 \\
\hline 压縮·曲げ強さ & JIS R 52011従って測定，供試体: $40 \times 40 \times 160 \mathrm{~mm} ，(\mathrm{~N}=3)$ \\
\hline 付着強さ & JIS A 69161二準拠して測定 \\
\hline 長さ変化率 & JIS A 1129に従って測定, 供試体: $40 \times 40 \times 160 \mathrm{~mm},(\mathrm{~N}=3)$ \\
\hline 透気係数 & RILEM TC116-PCDに準拠Lて測定，試験体: $\phi 15 \times \mathrm{h} 4 \mathrm{~cm}$ \\
\hline 細孔径分布 & $\begin{array}{l}\text { 日本コンクリートエ学協会 超流動コンクリート研究委員会報告集 (II) } \\
\text { 細孔径分布の測定方法 (水銀圧入法) }\end{array}$ \\
\hline
\end{tabular}

\section{3．試験結果および考察}

\section{3， 1 各種補修モルタルの基礎物性試験結果}

冬㮔補修モルタルの基礎物性試験結果を表一 5 に小す。例えばた維 強度が 18.5〜 57. 4 $\mathrm{M} / \mathrm{mm}^{2}$ の公範䎴となったように、モルタルの㮔類に よって基礎物性は人きく恭なった。また、今问の統一的な試験絬果に

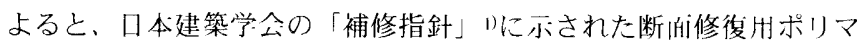
一セメントモルタルの品質基準（案）を淽足しないものも見られた。 補修モルタルとしての中性化抵抗性についても、26 造の促進試験で 仓く中性化が進行しないものから $12.8 \mathrm{~mm}$ と比較的中性化が進行する ものまで見られた。これらの基礎物性の中には、図ー2に例示する厈 緮強度と乾燥収維率の関係のように、相関関倸が比較的高いものと、 干緮強度と付着強度のように相関関係の低いものが見られた。
表－5 補修モルタルの基礎物性試験結果一覧

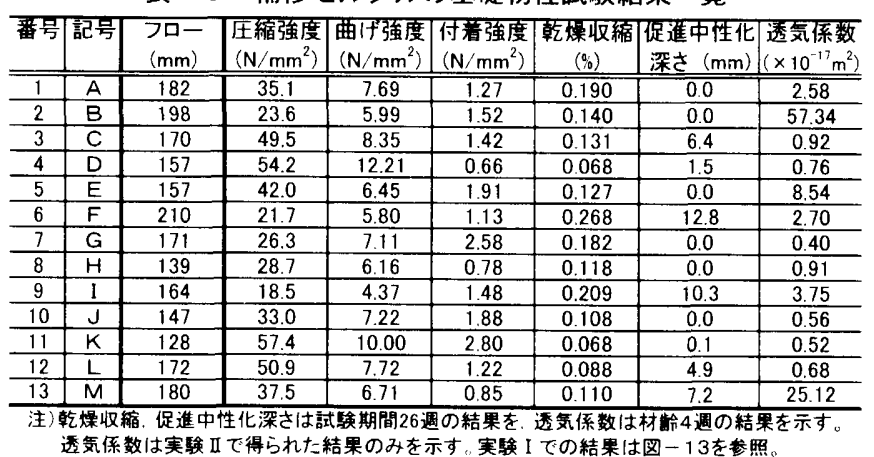

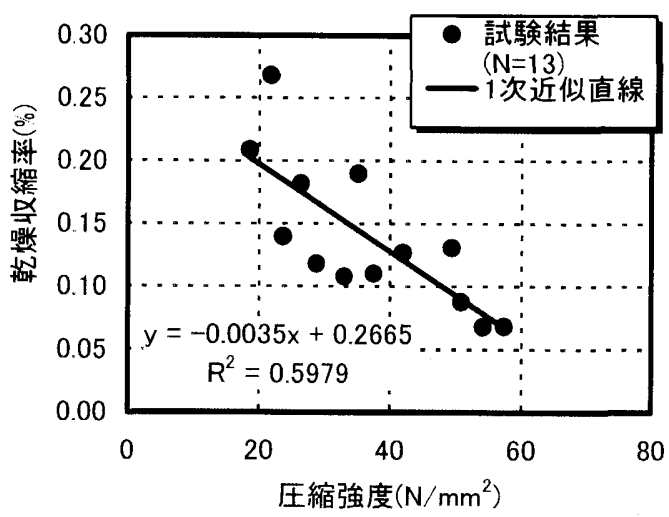

図-2＼cjkstart補修材料の圧縮強度と乾燥収縮率の関係

\section{2 各種補修モルタルの透気係数試験結果}

図ー3に、尖施した補修モルタルの透父倸数試験の概岁を示す。試

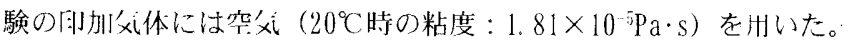

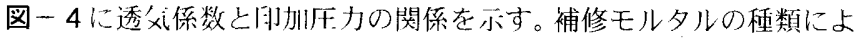

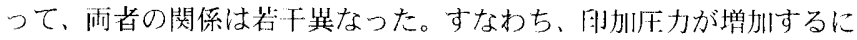
従って透父係数が若干小さくなる倬们を示すものと、印加厈力が堌加 しても透父倸数はほとんど変化しない補修モルタルが見られた。A材 料やI材料など透父係数が比較的人きい材料の透父係数に洱加厈力 の影響が見られた。但し、F材料のように透父倸数が比較的人きい材 
料でも、印か川厈力の影響が小さいものもある。本試験では、RILEM TC116-PCD に従って脚川厈力 1.5，2.0，3.0bar 時の測定絬果の平均 值を透狎倸数とした。

図ー5に透父係数と補修モルタルの材齢の関倸を示す。材齢の経過 に従って、透父係数が増人する倾向を示すもの、透父係数はほとんど 炃化しないもの、透父倸数が大きく変動するものが胃られた。この腙 以については、乾燥に伴う試験休の内部クラックの進行などの影響も 䒓えられることから、合後より答細な检封が必岁になるものと思われ る。本試験では、これらの惊凶の影響が比較的少ないと考えられる材 齢 4 遠での試験絬果をその補修材料の代表値とすることにした。

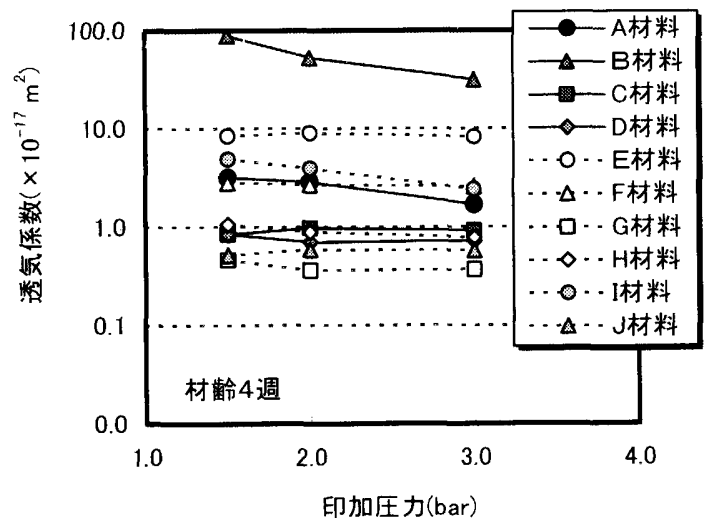

図-4 透気係数に及ぼす印加圧力の影響

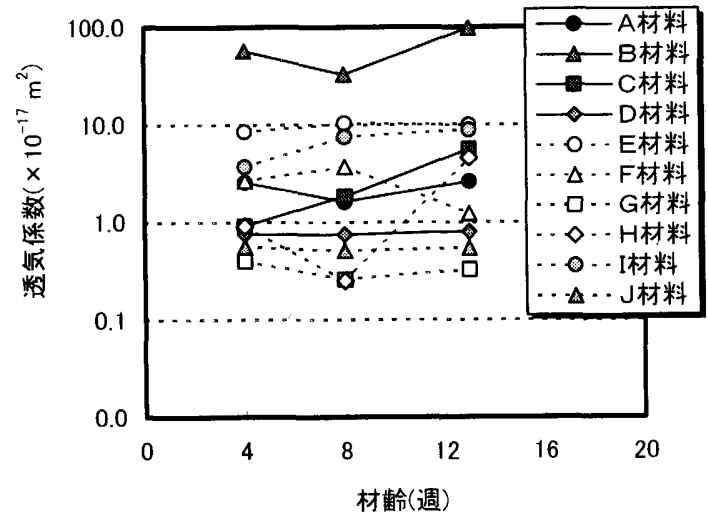

図ー 5 透気係数に及ぼす材歯の影響

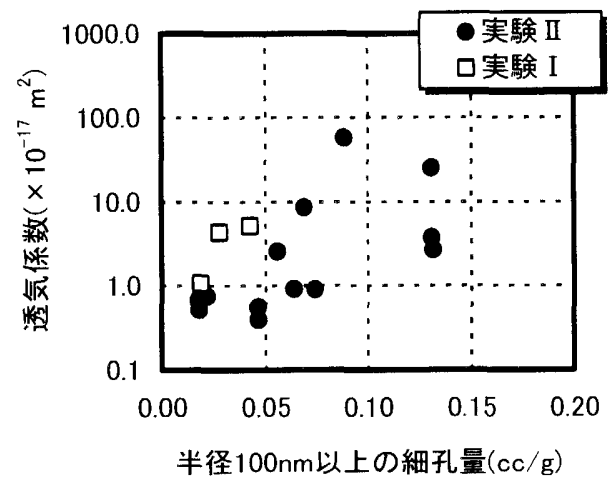

図-6 透気係数と半径が $100 \mathrm{~nm}$ 以上の細孔量の関係

尖験 Iの試験休作製時に川いた補修モルタルの透父係数の試験絬 果を表一 5 に併記する。透﨎倸数についてみると、B材料とG $\mathrm{G}$ 材料で は2 ケ夕も恭なる結果となった。これら透父倸数の絬果上前項に記し た補修モルタル白身の促進中性化の試験絬果は、外部からの炭酸ガス の遮蔽度や炭酸ガスと反心・消費するモルタル中のアルカリ哩が異な ることを示しており、補修モルタルを施したコンクリートの補修後の 中性化抑制効果が人きく恭なることが予想される。

图一6に透父係数亡半径が $100 \mathrm{~nm}$ 以!:の細孔革の関係を示す。既往.

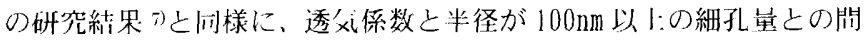
には、正の相関関倸がみられた。

3.3 補修時期が補修後のコンクリートの中性化抑制に及ぼす影響 図一７に、尖験 I でモルタルの補修時期を変えた場合の補修時期が コンクリートの中性化抑制効果に义ぼす影響を示す。無補修の場合に は、中性化深さと促進期開 $\mathrm{t}$ との片に一般に、 $\mathrm{t}$ 則の関係があること が知ら扎ている。本試験絬果でも，無補修の場合の中性化深さと、(促 進期閌)の閂には寄ケ率 $\mathrm{R}^{2}=0.997$ の艮好な直線関倸が見られた。これ に対して、補修後の中性化深さ $\mathrm{y}$ と促進期肅 $\mathrm{t}$ の䦌にも $\mathrm{y}=\mathrm{A}_{1}(\sqrt{ } \mathrm{t}$ $\left.-\sqrt{ } t_{n}\right)+B_{1}$, 直線閔倸 $\left(A_{1}\right.$ は補修後の中性化速度係数, $B_{1}$ は補修 時の中性化哚さ， $\mathrm{t}_{0}$ 注補修時期を少す)が見られた。奇ケ率 $\mathrm{R}^{2}$ ? 0.76 〜0.99であり、無補修の場合よりもその精度が若干低卜する程度の ものであった。齐補修時期での補修後の中性化速度係数 A，の計算緗 果を表一6に示す。この中性化速度係数 $\mathrm{A}_{1}$ について、補修時期（前 中性化哚さ）と補修材料の種類を岁因とした分散分析を行った結果、 表一 7 に示すように補修時期（前中性化深さ）の蚍いによってA、に 存意差は見られなかった。このことから、補修後の中性化深さは、補
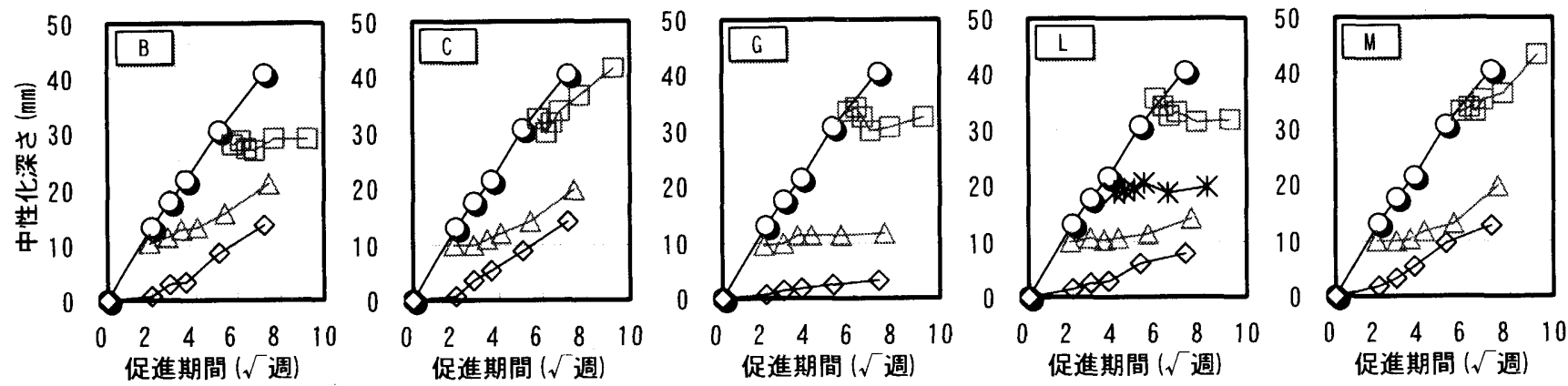

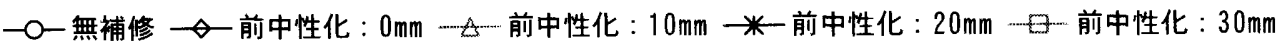

図一7 補修時期が中性化の抑制効果に及ぼす影響 
修の時期に関係なく、 $\mathrm{A}$ ，の平均值を川いて促進期閥 $\mathrm{t}$ と補修時期 $\mathrm{t}$ 。 の平力差 $\left(\sqrt{\mathrm{t}}-\sqrt{ } \mathrm{t}_{0}\right)$ を変数とした 1 次直線で示すことができるも のと考えることができる。

\section{表ー6 補修時期が補修後の中性化速度係数 $A_{1}$ に及ぼす影響}

\begin{tabular}{|c|c|c|c|c|c|}
\hline \multirow{3}{*}{ 補修材の種類 } & \multicolumn{5}{|c|}{ 中性化速度係数 $\mathrm{A}_{1}\left(\mathrm{~mm} /\left(\sqrt{\mathrm{t}}-\sqrt{ } \mathrm{t}_{0}\right)\right)$} \\
\hline & \multicolumn{5}{|c|}{ 前中性化深さ $(\mathrm{mm})$} \\
\hline & 0 & 10 & 20 & 30 & 平均値 \\
\hline B材料 & 1.98 & 1.92 & - & 0.39 & 1.43 \\
\hline C材料 & 2.05 & 1.79 & - & 3.14 & 2.33 \\
\hline G材料 & 0.46 & 0.38 & - & 0.00 & 0.28 \\
\hline L材料 $(\mathrm{W} / \mathrm{C}=40 \%)$ & 1.16 & 0.71 & 0.22 & 0.00 & 0.52 \\
\hline $\mathrm{M}$ 材料 $(\mathrm{W} / \mathrm{C}=50 \%)$ & 1.90 & 1.76 & - & 2.89 & 2.18 \\
\hline 無補修コンクリート & 5.62 & - & - & - & - \\
\hline
\end{tabular}

表-7 補修時期が中性化速度係数に及ぼす影響の分散分析結果

\begin{tabular}{c|c|c|c|c|c|c}
\hline 変動要因 & 変動 & 自由度 & 分散 & 分散比 & $\mathrm{F}$ 境界値 & 判定 \\
\hline \hline 補修材料 & 9.98 & 4 & 2.49 & 4.91 & 3.84 & $5 \%$ 有意 \\
\hline 前中性化深さ & 0.15 & 2 & 0.08 & 0.15 & 4.46 & 有意差なし \\
\hline 誤 差 & 4.06 & 8 & 0.51 & & & \\
\hline \hline 合 計 & 14.20 & 14 & & & & \\
\hline
\end{tabular}

\section{4 補修モルタルの種類が補修後のコンクリートの中性化抑制に} 及ぼす影響

次に、尖験】において各種補修材を川いた場合の中性化抑制效果在 調べた試験絬果を図ー8，9に示す。冬硬補修材を施した場命につい

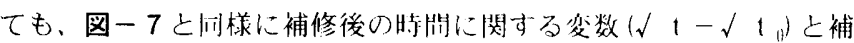

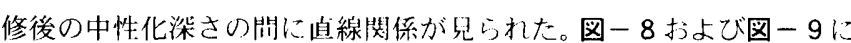
示すように、B材料のように中性化の抑制効果が小さい材料と、(;材

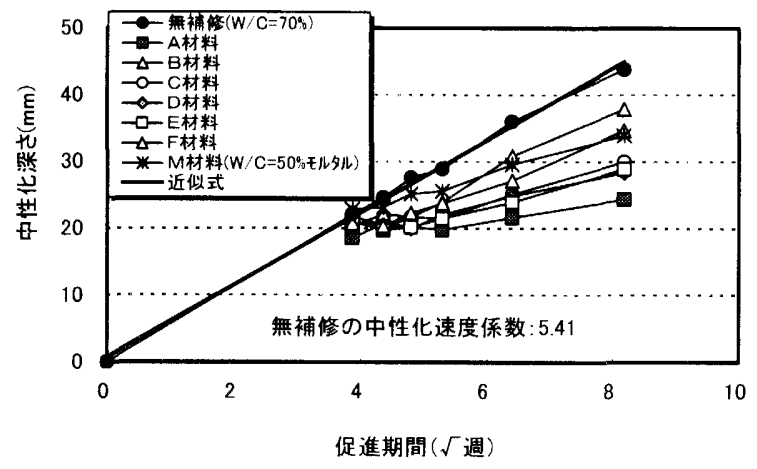

図-8 各種補修材の中性化抑制効果（ $A \sim F$ 材料，M材料）

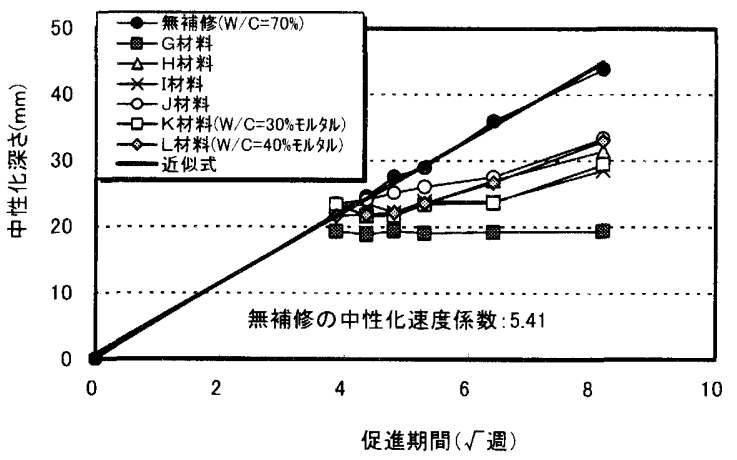

図－9 各種補修材の中性化抑制効果（G〜L材料）
料のように中性化の抑制効果が人きい材料があった。補修後の中性化 速度係数 $\mathrm{A}_{1}$ でみると、補修材の㮔類によって無補修の場合の中性化 速度係数 Aの0〜79\%と中性化抑制効果が人きく恭なった。これらの ことから、補修により延命化する場合には、必岀となる余寿命が付ケ. されるように、適切な補修材料を選定する必鬼があるものと言える。

\section{5 中性化抑制効果に及ぼす躯体コンクリートの種類の影響}

水セメント比が $50 \%$ のコンクリート試験体を师いて補修後の中性 化抑制効果を夙べた垁験皿の絬果を図ー10 に示す。水セメント比が $50 \% の$ 場合も $70 \%$ の場合之闰梯に、補修後の中性化深さと変数 $(\sqrt{\mathrm{t}}$ - $\left.\sqrt{ } \mathrm{t}_{0}\right)$ の閁に陌線関係が見られた。また、無補修の中性化速度倸数 に刘する補修後の中性化述度係数の比率は 14 61\%で、水セメント 比が $70 \%$ の場合と同梯に、補修モルタルによる中性化抑制の効果が

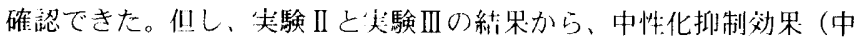
性化速度係数の比率）に㪀ぼす躯休コンクリートの水セメント比の影 響を直接比較することはできない。これは補修材料のロット差などに より透父倸数などの物性が若干恭なるためである。この躯休コンクリ 一トの水セメント比の影響については、3.7 項で步察する。

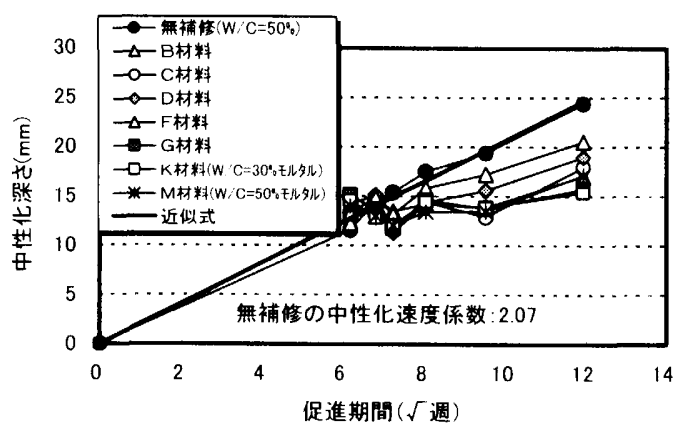

図-10 各種補修材の中性化抑制効果（W/C=50\%の場合）

3. 6 補修モルタルによる補修後のコンクリートの中性化抑制効果 の予測に関する検討

図ー11(1)，(2)に、失験 I で失施した前中性化深さ0 $\mathrm{mm}$ の場合の補 修後の中性化試験絬果の例を示す。補修モルタルに木中性化部分が残 つているにも関わらず、コンクリートの中性化が進行しているのがわ かる。図ー12 は、尖験 IIに打ける補修後のコンクリートの中性化深 さおよび補修モルタル部分の中性化深さと促進期開の関係を示した ものである。间図によると、補修後のコンクリートにおいては、補修・ 被覆モルタル部分の中性化の進行の有無上は無関倸に、コンクリート 郭分の中性化が進行する。これらの結果は、補修後のコンクリートの 中性化の進行に、補修材の透父倸数が影響することを示している。

条種補修析で補修した場合の中性化速度倸数を無補修の場合で無 次它化した中性化速度係数の比をここでは寿命予测倸数 $\mathrm{A}_{1} / \mathrm{A}$ とし た。尖験 I，II の試験結果において、後述する多変最解析の精度を向 にささせることと、将来的に他の影響岀因を考虑していくことを甘的に、 价物性値がいずれも人きい材料の 1 つであるW/C=50\%モルタルの值で 無次儿化した補修材白身の中性化述度係数亡透父倸数が、この $\mathrm{A}_{1} / \mathrm{A}$ に及ぼす影響を図ー13，図ー14 に示す。図ー13に示すように、例え ば補修材白体の中性化速度係数が 0 である $\mathrm{B}$ 材は、问值が比較的人き い G，L材より尀命予測係数が大きく、透父係数の影響が何われる。 
図ー14に示すように、俦命予測倸数 $\mathrm{A} / \mathrm{A}$ に必ぼす補修材白身の中性 化速度係数および透父倸数の無次儿化量の閂には正の相関関係が見 られた。また、補修材料の細孔量も寿命予测係数 $\mathrm{A}_{1} / \mathrm{A}$ 汇影響を及ぼ すものと推測されるが、3.2 項に示したように透父倸数と半径 $100 \mathrm{~nm}$ 以 $1: の$ 細孔最との閂に正の相関関係があり、透父係数上半径 $100 \mathrm{~nm}$ 以 は:の細孔星を独け変数として扱うことはできない。そこで、この垁験 II の試験絬果を剌いて、寿命予测係数 $\mathrm{A}_{1} / \mathrm{A}$ を補修材の特性值である 透父倸数之中性化速度倸数から求める式(1)を多变星解析にて求めた。

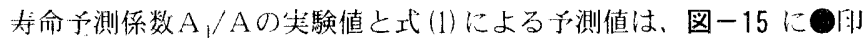
でホすように比輷的哀好な刘心を示した。
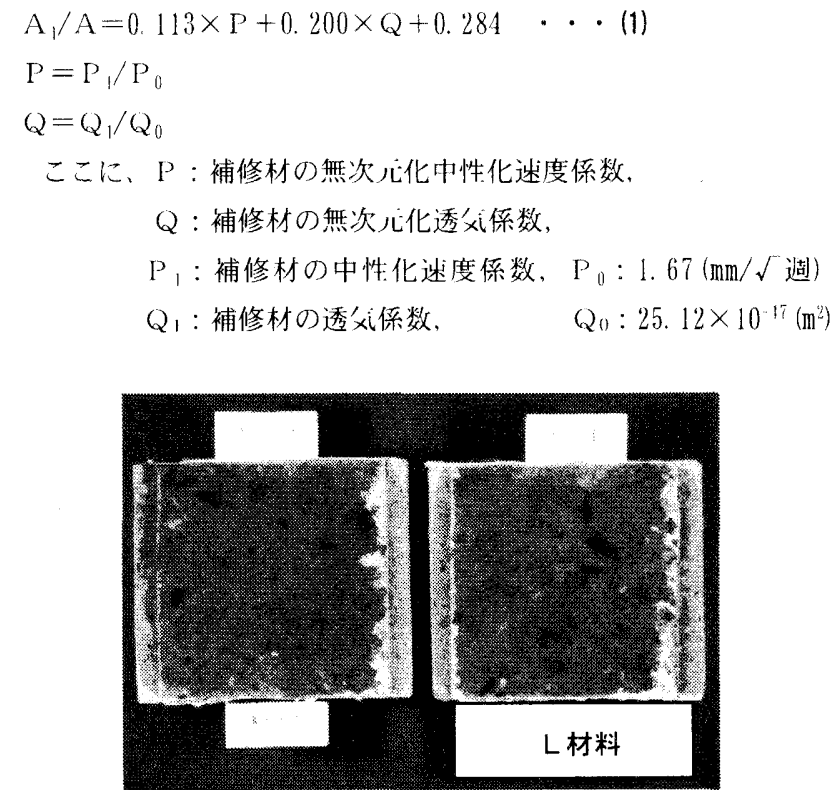

（1）実験 Iにおける前中性化深さ $0 \mathrm{~mm}$ の中性化試験結果 (促進期間 13 週のL材料)

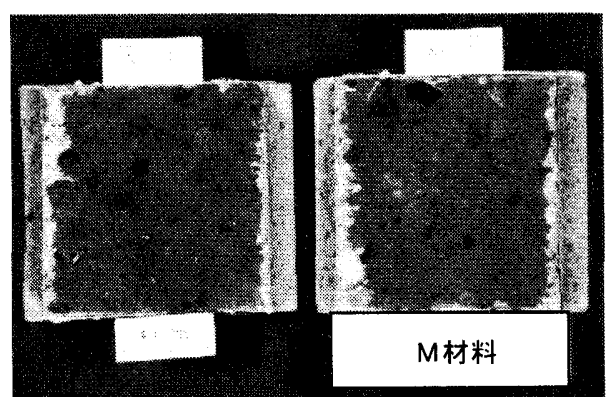

(2) 実験 I における前中性化深さ $0 \mathrm{~mm}$ の中性化試験結果 （促進期間 13 週のM材料）

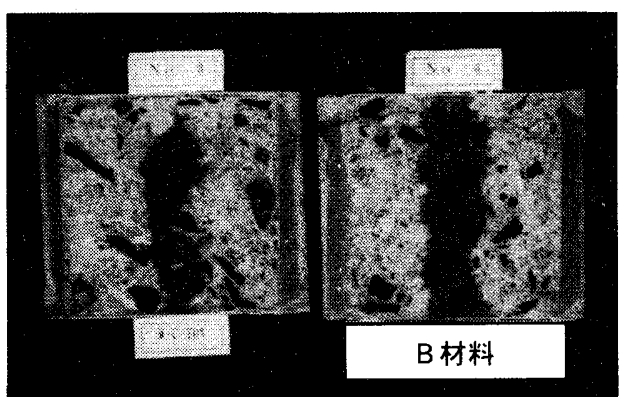

(3) 実験 II における前中性化深さ $20 \mathrm{~mm}$ の中性化試験結果 (促進期間 52 週のB材料)

図ー11 コンクリートおよび補修材の中性化試験結果

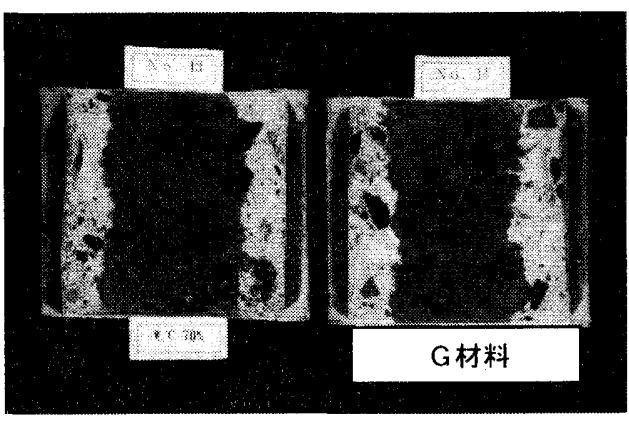

(4) 実験 II における前中性化深さ $20 \mathrm{~mm}$ の中性化試験結果 （促進期間 52 週の G材料）

図ー11 コンクリートおよび補修材の中性化試験結果

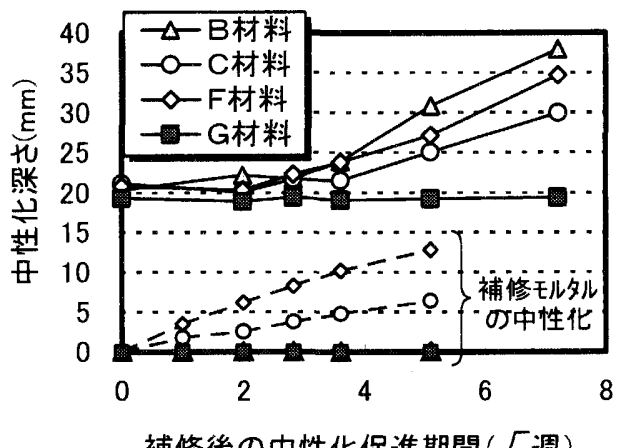

補修後の中性化促進期間 $(\sqrt{ }$ 週)

図ー12 コンクリートおよび補修材の中性化の進行状況

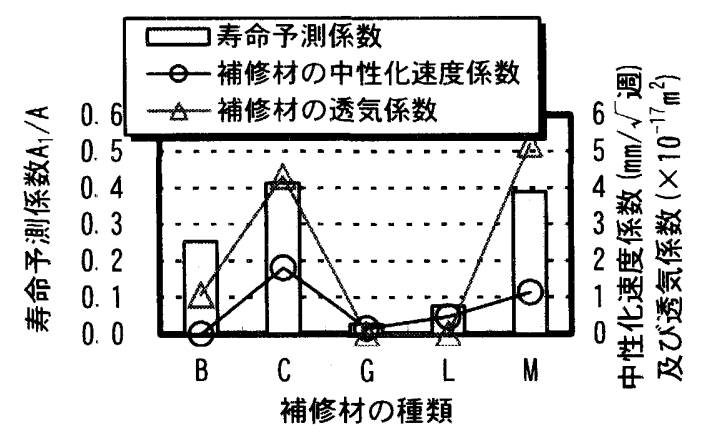

図一-13 補修モルタルの特性が $A_{1} / A$ に及ぼす影響 (1)

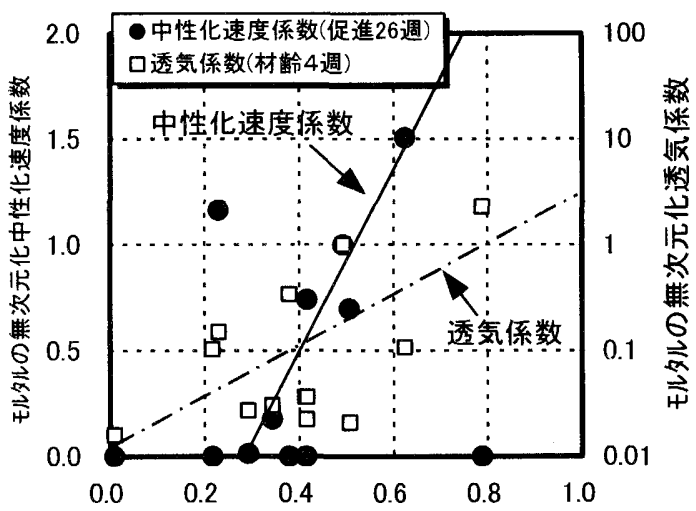

コンクリートの無次元化中性化速度係数 $A_{1} / A$

図一14 補修モルタルの特性が $A_{1} / A$ に及ぼす影響 (2) 


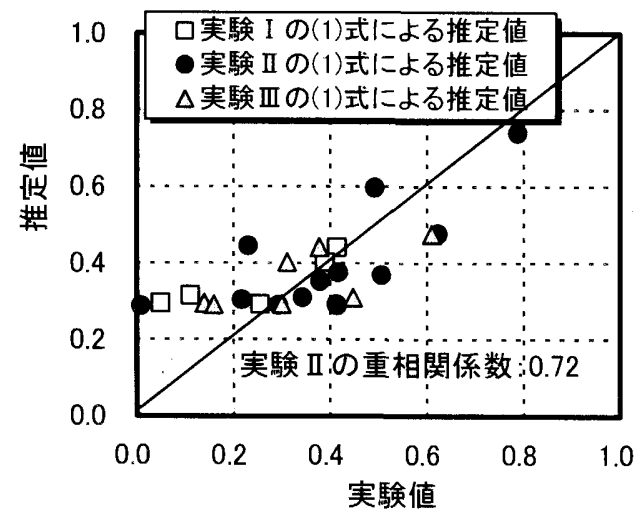

図-15 寿命予測係数 $A_{1} / A$ の実験值と予測值の関係

\section{7 中性化抑制効果予測手法の有効性検討と補修材料選定フロー}

尖験 1 の尖験值と式(1)による推定值の相関を図ー15に併記する。 中性化速度倸数、透父係数の無次儿化は、尖験 II M 材の值によっ

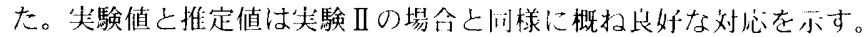
躯体コンクリートの水セメント比が $50 \%$ である尖験而の起験值之 式(1)による推定值の関係を図ー15に併記する。身体コンクリートの 水セメント比が $50 \%$ の場合にも、補修後の中性化抓制效果は式(1)で 推定できるものと考えられる。このことから、本尖験の笔㱛である水

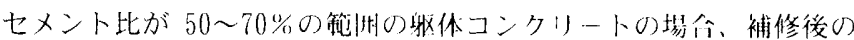
中性化抑制効果、すなわ，尤命兮测倸数 $\Lambda / \Lambda$ は躯体コンクリ一トの 水セメント比に関係なく、ほぼけじであるもの上推測される。

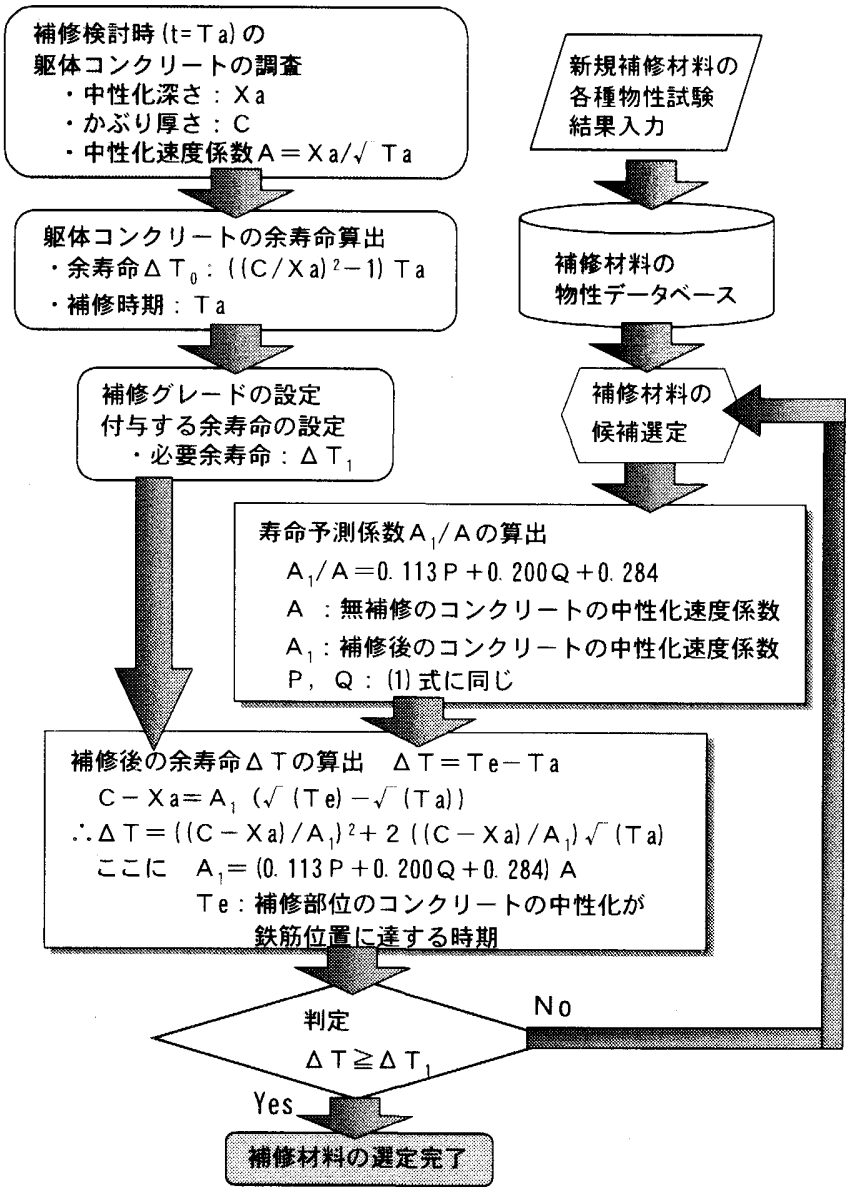

図-16 延命化予測のための補修材料選定フロー案
以 $\mathrm{I}$ ，尖験 $\mathrm{I} \sim$ IIIのそれぞれの尖験絬果と補修後の中性化抑制効果 の予测值がほぼ问じ関倸を示すことから、本予測于法の有効性がある 程度小せたものと考えられる。

本予测于法を州いた、延命化予测に必岁な補修材料の選定フロー案 を図ー16 に示す。本研究の範洲に抢いて、延命化に必岁な補修材料 の選定が问図によって川能になるものと考えられる。尚介後は、補修 モルタルの塗咛さや劣化等の影響を検封し、考慮していく必岀がある。

\section{4. 結論}

本尖験的研究によって得られた知見を以トにまとめる。

1)補修後のコンクリートの中性化深さ $\mathrm{y}$ と促進期開 $\mathrm{t}$ の婣には、 $\mathrm{y}=$ $\mathrm{A}_{1}\left(\sqrt{ } \mathrm{t}-\sqrt{ } \mathrm{t}_{0}\right)+\mathrm{B}_{1}$ の直線関係 $\left(\mathrm{A}_{1}\right.$ 注補修後の中性化速度係数, $\mathrm{B}$ ，注補修時の中性化媣さ， $\mathrm{t}_{\|}$は補修時期を示す）がある。

2)乔硬補修モルタルによる補修後の中性化述度倸数は W/C $=70 \%$ のコ ンクリートの無補修の場合の0〜 79\%で、材料によって恭なった。 3)補修時の前中性化深さは、各種補修モルタルによる補修後の中性化 速度係数に影響を及ぼさないものと考えられる。

4)各枆補修モルタルによる補修後の中性化抑制効果は $W / C=50 \sim 70 \%$ の範抈では、躯休コンクリーートの水セメント比に影響を及ぼさない 上䒓元られる。

5)補修材の中性化抑制效果を标命予测係数上し、補修材向身の中性化

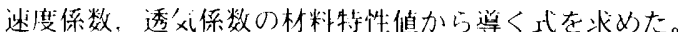

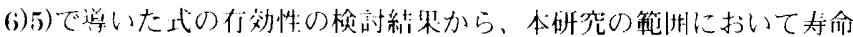
予测倸数は中性化速度係数上透猁数をパラメータとした推定式 で推足叮能であると考えられる。

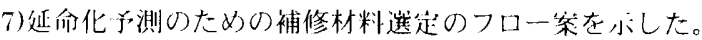

\section{謝辞}

本研究は、平成 13 年度〜平成 15 年度の経济商業彷次川代住宅技術 開発(資源衔噮型住毛に倸るものに限る)に関する丕䚶研究成果による ものであり、関倸者冬位に㴬意を表します。

\section{[引用文献]}

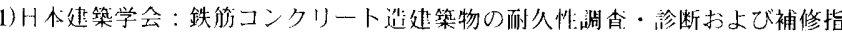

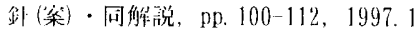

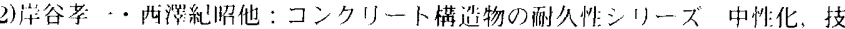

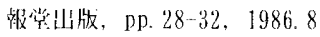

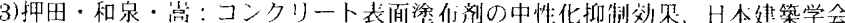
大会学術满演㤦慨集（北海道），A，pp. 265-266，1986.8

4)鈴木・大菬：補修用ポリマーセメントモルタルの中性化速度式の愉討，H本 建築学会大会学術满演㳏概集 (北陸) A - 1, pp. 149-150, 20028 8

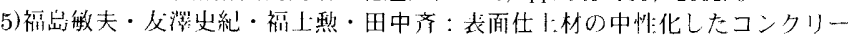

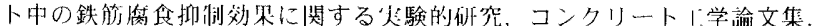
pp. 83-93, Vol. 10, No. 2, 1999.5

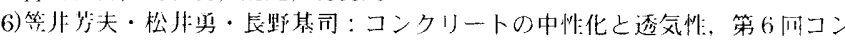
クリー-上に学件次满演会諭文集，pp. 189-192，1984

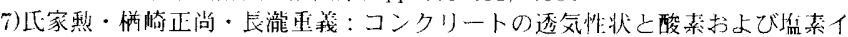

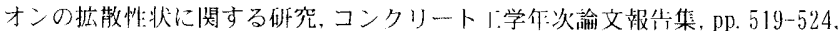
Vol. 15. No. 1, 1993

8)非! ・柳橋・池尾・洲：各種補修モルタルを用いたコンクリート身体の延

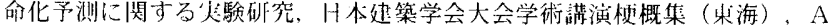
1, pp. $541-542,2003.9$

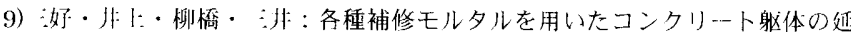

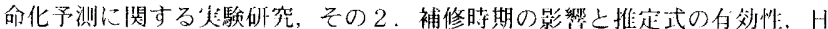
本建築学会大会学術满演㤦概集（北海道），A-1，pp. 1011-1012，2004.8 